ing appraisal be made by interested participants and observers alike; it is to be hoped that these will have the purpose and the effect of stimulating an ever more critical approach to the problems that beset us."

Address correspondence to: Jesse Roth, North Shore-Long Island Jewish Health System, 400 Lakeville Road, Suite 220, New Hyde Park, New York 11040, USA. Phone: (718) 470-7724; Fax: (516) 437-7717; E-mail: jesserothmd@hotmail.com. Or to: C. Ronald Kahn, Joslin Diabetes Center, One Joslin Place, Boston, Massachusetts 02215, USA. Phone: (617) 732-2635; Fax: (617) 732-2684; E-mail: c.ronald.kahn@joslin.harvard.edu.

1. Yalow, R.S., and Berson, S.A. 1960. Immunoassay of endogenous plasma insulin in man. J. Clin. Invest 39:1157-1175.

2. Himsworth, H.P. 1936. Diabetes mellitus: its differentiation into insulin-sensitive and insulin-insensitive types. Lancet. i:127-130.

3. Yalow, R.S. 1978. Radioimmunoassay: a probe for the fine structure of biologic systems. (Nobel Lecture, 8 December 1977). Science. 200:1236-1245.

4. Yalow, R.S., Glick, S.M., Roth, J., and Berson, S.A. 1965. Plasma insulin and growth hormone levels in obesity and diabetes. Ann. N. Y. Acad. Sci. 131:357-373.

5. Berson, S.A., Yalow, R.S., Bauman, A., Rothschild, M.A., and Newerly, K. 1956. Insulin-I131 metabolism in human subjects: demonstration of insulin binding globulin in the circulation of insulin treat- ed subjects. J. Clin. Invest. 35:170-190.

6. Megyesi, K., Kahn, C.R., Roth, J., and Gorden, P. 1974. Hypoglycemia in association with extrapancreatic tumors: demonstration of elevated plasma NSILA-s by a new radioreceptor assay. J. Clin. Endocrinol. Metab. 38:931-934.

7. Straus, E. 1998. Rosalyn Yalow, Nobel laureate: her life and work in medicine: a biographical memoir. Plenum Trade. New York, New York, USA. 277 pp.

8. Gellhorn, E., Feldman, J., and Allen, A. 1941. Assay of insulin on hypophysectomized, adreno-demedullated, and hypophysectomized-adreno-demedullated rats. Endocrinology. 29:137-140.

9. Anderson, E., Wherry, F.E., and Bates. R.W. 1961. Method of extraction and bio-assay of insulin in blood. Diabetes. 10:298-303.

10. Groen, J., Kamminga, C.E., Willebrands, A.F., and Blickman, J.R. 1952. Evidence for the presence of insulin in blood serum; a method for an approximate determination of the insulin content of blood. J. Clin. Invest. 31:97-106.

11. Renold, A.E., et al. 1960. Measurement of small quantities of insulin-like activity using rat adipose tissue. I. A proposed procedure. J. Clin. Invest. 39:1487-1498.

12. Berson, S.A., and Yalow, R.S. 1965. Some current controversies in diabetes research. Diabetes. 14:549-572.

13. Antoniades, H.N. 1961. Studies on the state of insulin in blood: the state and transport of insulin in blood. Endocrinology. 68:7-16.

14. Samaan, N., Fraser, R., and Dempster, W.J. 1963. The "typical" and "atypical" forms of serum insulin. Diabetes. 12:339-348.

15. Froesch, E.R., Buergi, H., Ramseier, E.B., Bally, P., and Labhart, A. 1963. Antibody-suppressible and nonsuppressible insulin-like activities in human serum and their physiologic significance. An insulin assay with adipose tissue of increased precision and specificity. J. Clin. Invest. 42:1816-1834.
16. Zapf, J., Schoenle, E., and Froesch, E.R. 1978. Insulin-like growth factors I and II: some biological actions and receptor binding characteristics of two purified constituents of nonsuppressible insulin-like activity of human serum. Eur. J. Biochem. 87:285-296.

17. Devendra, D., and Eisenbarth, G.S. 2003. 17 Immunologic endocrine disorders. J. Allergy. Clin. Immunol. 111:S624-S636.

18. Hirata, Y., Tominaga, M., Ito, J.I., and Noguchi, A. 1974. Spontaneous hypoglycemia with insulin autoimmunity in Graves' disease. Ann. Intern. Med. 81:214-218.

19. Boden, G., and Shulman, G.I. 2002. Free fatty acids in obesity and type 2 diabetes: defining their role in the development of insulin resistance and beta-cell dysfunction. Eur. J. Clin. Invest. 32(Suppl. 3):14-23.

20. Roth, J., et al. 1975. Receptors for insulin, NSILA-s, and growth hormone: applications to disease states in man. Recent Prog. Horm. Res. 31:95-139.

21. Virkamaki, A., Ueki, K., and Kahn, C.R. 1999. Protein-protein interaction in insulin signaling and the molecular mechanisms of insulin resistance. J. Clin. Invest. 103:931-943.

22. Dandona, P., Aljada, A., and Bandyopadhyay, A. 2004. Inflammation: the link between insulin resistance, obesity and diabetes. Trends Immunol. 25:4-7.

23. Flier, J.S., Kahn, C.R., and Roth, J. 1979. Receptors, antireceptor antibodies and mechanisms of insulin resistance. N. Engl. J. Med. 300:413-419.

24. Taylor, S.I., and Arioglu, E. 1998. Syndromes associated with insulin resistance and acanthosis nigricans. J. Basic Clin. Physiol. Pharmacol. 9:419-439.

25. Stadie, W.C., Haugaard, N., and Vaughan, M. 1952. Studies of insulin binding with isotopically labeled insulin. J. Biol. Chem. 199:729-739.

26. Newerly, K., and Berson, S.A. 1957. Lack of specificity of insulin-I 131-binding by isolated rat diaphragm. Proc. Soc. Exp. Biol. Med. 94:751-755.

\title{
Superoxide production by phagocytic leukocytes: the scientific legacy of Bernard Babior
}

\section{John T. Curnutte}

DNAX Research Institute, Palo Alto, California, USA.

\begin{abstract}
It was 32 years ago that Bernard Babior, Ruby Kipnes, and I submitted a paper to the JCI reporting that polymorphonuclear leukocytes produce superoxide $\left(\mathrm{O}_{2}^{-}\right)$during phagocytosis and that this highly reactive oxygen radical might function as a microbicidal agent. The story of how our lab came to this discovery is one of a special relationship between a student and his brilliant mentor.
\end{abstract}

We were pleasantly surprised in 1972 to hear that our paper (1) had been accepted for publication. We were even more surprised recently to learn that this report was among

Nonstandard abbreviations used: CGD, chronic granulomatous disease; $\mathrm{HOCl}$, hypochlorous acid; $\mathrm{O}_{2}^{-}$, superoxide.

Conflict of interest: The author has declared that no conflict of interest exists.

Citation for this article: J. Clin. Invest. 114:1054-1057 (2004). doi:10.1172/JCI200423377. the JCI's most frequently cited articles and was to be highlighted as part of the Journal's 80th-anniversary celebration. There was a sad irony, though. Within a few weeks after Bernie (Figure 1) enthusiastically agreed to write a historical commentary on the article, a lingering illness intensified that led to his passing on June 29, 2004. He was not able to share with us his perspectives 3 decades after one of his most important discoveries. I was honored to be asked by the JCI to step in for Bernie to write the commentary and, in the process, to pay tribute to this wonderful, creative, and spirited investigator and man.

The story behind our article has, as many discoveries do, an unlikely origin - in this case, a growing special relationship between a student and his mentor. I was a freshman at Harvard College, majoring in biochemistry and in search of an adviser, and learned that there was a brilliant young professor of medicine and gastroenterologist at Harvard Medical School's Thorndike Laboratory at Boston City Hospital - Bernard Babior - who was also a tutor in the Biochemistry Department at the college. He agreed to take me under his wing and for the next 2 years patiently taught me the complex biochemistry of vitamin $\mathrm{B}_{12}$ in rigorous one-on-one tutorials and, eventually, at the bench in his laboratory (Figure 2). 


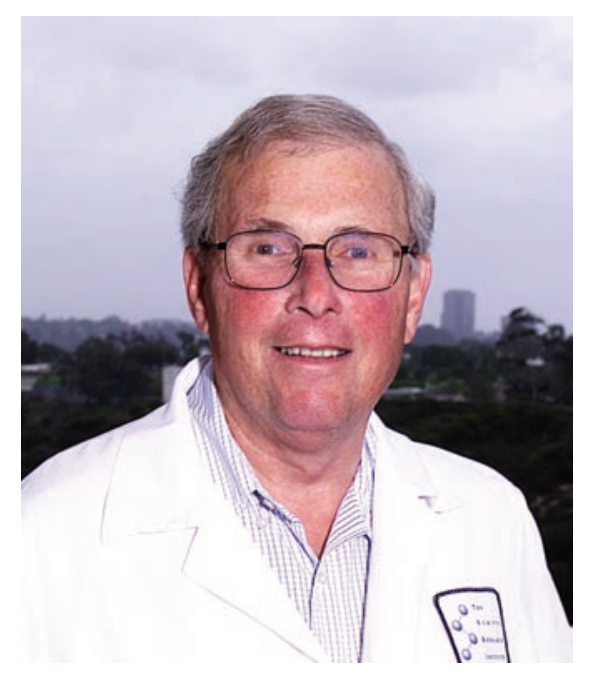

Figure 1

Bernard M. Babior (1935-2004) at his laboratory at The Scripps Research Institute.

While I was inspired by Bernie's passion for the study of cobalamin-dependent enzymes and the sophisticated intricacies of his experiments, I was even more drawn to the hematology research 2 floors below at the Thorndike in the laboratories of William Castle (then an emeritus professor), James Jandl, and H. Franklin Bunn. I finally found the courage to tell Bernie that my interests were in hematology and that I wanted to do research on blood cells instead of vitamin $\mathrm{B}_{12}$. Rather than expressing disappointment, he looked at me first with fatherly understanding and then with an intense excitement in his eyes that I had come to learn signaled the beginning of one of his creative surges. Bernie told me that he was fascinated by the biology of phagocytosis and had been following several disparate areas of investigation in the literature that led him to a hypothesis about a potentially novel mechanism by which leukocytes might kill microbes - one involving superoxide $\left(\mathrm{O}_{2}^{-}\right)$. For the next hour, he explained the evolution of his thinking. He was intrigued by the work of Irwin Fridovich and his colleagues at Duke University showing that biologic systems could generate superoxide. This highly reactive oxygen radical was produced by enzymes such as xanthine oxidase in the course of their normal catalytic function (2) or during the oxidation of hemoglobin to methemoglobin (3). To counterbalance the potentially harmful effects of this oxygen free radical, cells also contain an enzyme to destroy superoxide - superoxide dismutase (4). Bernie was particularly struck by the observation that microbes that were obligate anaerobes lacked superoxide dismutase, while those that could survive in oxygen contained this protective enzyme (5).

The link to phagocytosis came from several other reports. One, from the laboratory of Manfred Karnovsky, showed that while phagocytic leukocytes could ingest bacteria under anaerobic conditions, oxygen was required for the efficient destruction of microorganisms (6). In conjunction with phagocytosis, a "respiratory burst" occurred, in which increased amounts of oxygen were consumed by neutrophils, not by mitochondrial oxidative phosphorylation, but by a cyanide-insensitive pathway leading to the production of hydrogen peroxide $\left(\mathrm{H}_{2} \mathrm{O}_{2}\right)(6,7)$. Another article from the laboratory of Seymour Klebanoff demonstrated that myeloperoxidase, present in abundant amounts in the azurophil granules of neutrophils, catalyzed a reaction between the newly generated $\mathrm{H}_{2} \mathrm{O}_{2}$ and halide ions $\left(\mathrm{Cl}^{-}\right.$or $\left.\mathrm{I}^{-}\right)$to produce hypochlorous acid (HOCl or HOI) (8). There was no doubt in Bernie's mind that $\mathrm{HOCl}$ played an important role in phagocytic killing (a point he would later emphasize while poolside at swimming parties with members of his lab!). He was puzzled, though, by a report from Robert Lehrer and Martin Cline that patients with a congenital deficiency in myeloperoxidase had minimal problems clearing infections except in special circumstances such as diabetes (9). Bernie reasoned that there must be other oxygen-dependent killing mechanisms. He thus hypothesized that phagocytic leukocytes might be capable of catalyzing the 1-electron reduction of oxygen to $\mathrm{O}_{2}{ }^{-}$in addition to (or instead of) the 2-electron reduction to $\mathrm{H}_{2} \mathrm{O}_{2}$ and that this oxygen radical could be part of the microbicidal system of the cell.

It didn't take me long to decide that this was the project I wanted to pursue. The process also deepened my affection and respect for Bernie as he tried to find an area of research that would best fit with my interests. I read the stack of papers he gave me and found additional references. In a few days, the initial experiments began. The first challenge was to decide on the type of cells to study. We agreed neutrophils would be the best, but Bernie, ever the biochemist, thought we should use guinea pig-derived peritoneal cells, while I argued for fresh circulating human neutrophils, since we could, if successful, expand our work to patients with infections or immunodeficiencies. Bernie supported my recommendation, and after a few weeks, I was able isolate human neutrophils. The first few weeks of experiments were frustrating, because I could see no evidence of superoxide production using tetranitromethane as the detector. Neither Bernie nor I were accomplished cell biologists, so it did not immediately occur to us that this reagent might be toxic to the cells! Fortunately we realized this, switched to a "gentler" cytochrome $c$ detector, and were able to see low levels of cytochrome $c$ reduction after the addition of latex particles to the neutrophils (which were avidly phagocytized). The elegant work of McCord and Fridovich on superoxide dismutase enabled us to demonstrate that the cytochrome $c$ reduction was due to superoxide, as the increase seen during phagocytosis was largely inhibited by the dismutase. It was then that I learned one of my first major experimental lessons from Bernie - the need for extensive controls. Every constituent in the experimental reaction was first omitted and then replaced by a boiled inactivated form. Cytochrome $c$ spectra were carefully analyzed to check for authenticity of reduced cytochrome. Kinetics were measured, albeit roughly. Ruby Kipnes, Bernie's gifted technician, who had already been schooled in his rigorous approach to control experiments, provided a keen eye to make sure the controls met Bernie's high standards.

In retrospect, it is remarkable that we were able to measure the increase in superoxide under the experimental conditions we used. The rate of superoxide production was approximately $0.1 \mathrm{nmol} \mathrm{O}_{2}^{-} / \mathrm{min}$ per $10^{7}$ cells, just 2 -fold greater than the "resting" rate seen in cells not undergoing phagocytosis. We later learned that serumopsonized bacteria were much more potent stimulators of superoxide production (10) and could result in rates of more than 100 $\mathrm{nmol} \mathrm{O} 2^{-} / \mathrm{min}$ per $10^{7}$ cells - a rate that represents a several-hundred-fold increase over that seen in resting neutrophils. Thanks to the extensive replicate controls we performed in our initial latex experiments, though, we were able to establish with confidence that superoxide production increased upon phagocytic stimulation.

The anticipated advantage of using human neutrophils proved valuable shortly thereafter. Bernie and I attempted to discover whether superoxide production might be defective in neutrophils from patients with chronic granulomatous disease (CGD). This rare neutrophil disorder is characterized by severe, recurrent bacterial and fungal infections that usually begin in infancy and can 


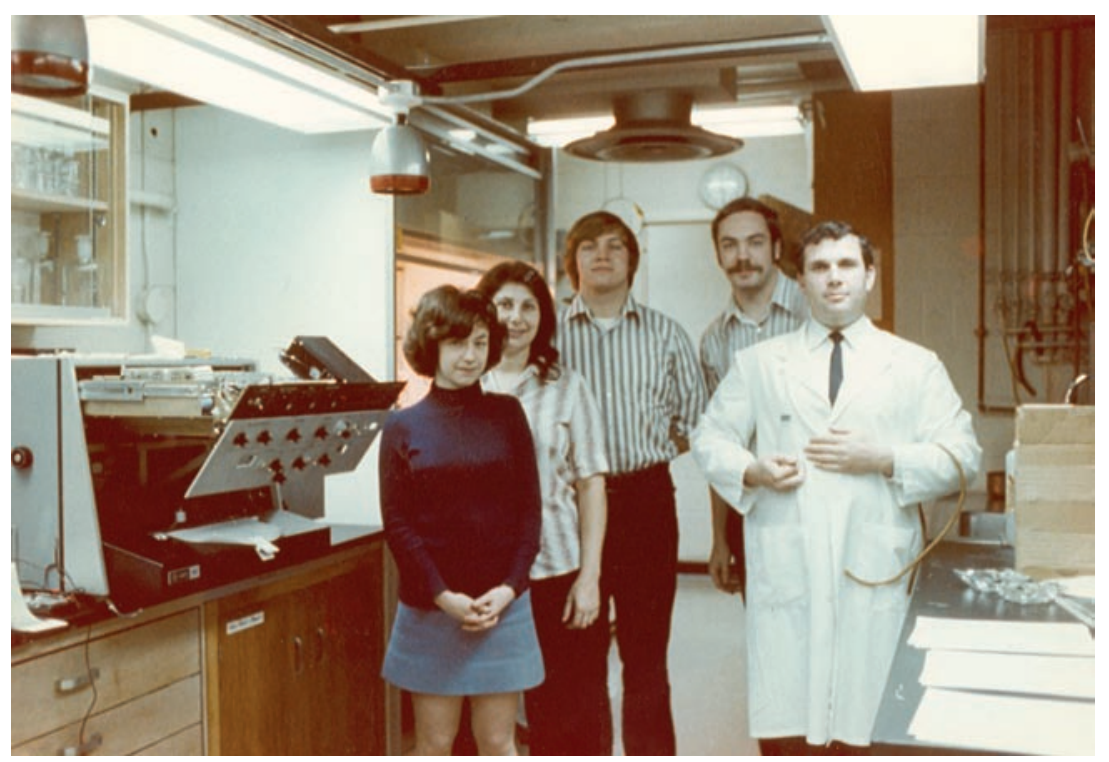

Figure 2

The Babior laboratory at the New England Medical Center in February 1973. Left to right: Ruby S. Kipnes, Michel Walke, John T. Curnutte, William E. Hull, and Bernard M. Babior.

lead to death. It had been learned in Robert Good's laboratory that the neutrophils from these patients did not undergo a respiratory burst when stimulated (11), nor did they generate hydrogen peroxide (12). We reasoned that if superoxide was truly a product of the phagocytic respiratory burst, it should not be detectable in the stimulated neutrophils from CGD patients. In collaboration with Dana Whitten, a pediatric hematologist from the New England Medical Center, we studied 2 young children with CGD and found that neither produced detectable levels of superoxide (13). Thus, our hypothesis about the relation of superoxide to the respiratory burst - and its possible role in host defense - was strengthened by this important study.

I remember that at the time we first demonstrated superoxide production in stimulated neutrophils, Bernie predicted that this finding would have far-ranging importance both in the phagocyte field and elsewhere in biomedical research. I couldn't see the future as clearly as he did, but reflecting on the past 3 decades of research, I realize that Bernie was correct. He anticipated that the cytochrome $c$ assay (using superoxide dismutase in the control reaction mixture or cuvette) would turn out to be a highly sensitive method for measuring the kinetics of the respiratory burst in a variety of phagocytic cells under a wide range of conditions, a marked improvement over the cumbersome low-throughput methods for measuring oxygen consumption (or even $\mathrm{H}_{2} \mathrm{O}_{2}$ production). Indeed, the assay was eventually adapted to highthroughput microwell plates using kinetic microplate readers. Bernie also predicted that the prevailing uncertainty regarding the enzymatic basis of the respiratory burst (a soluble NADH oxidase or particulate NADPH oxidase) could be resolved by determining which produced superoxide in quantities that reflected the rates produced in intact neutrophils. This again proved true, as NADPH oxidase was ultimately established as the respiratory burst enzyme based on its ability to generate superoxide at a rate that was commensurate with that seen in stimulated neutrophils (14) and its lack of catalytic activity in homogenates of CGD leukocytes (15). Measuring superoxide production as an indicator of NADPH oxidase activity also greatly facilitated the discovery of cell-free systems to activate this enzyme, which, in turn, led to the identification of its 5 subunits and associated regulatory G proteins (16).

Another early prediction by Bernie came true. He reasoned that once phagocytes generate an oxygen-free radical such as superoxide, a potential "Pandora's box" of other reactive oxygen intermediates might possibly be opened, leading to production of not only hydrogen peroxide and $\mathrm{HOCl}$, but also singlet oxygen, hydroxyl radical, and even ozone. All were subsequently shown to be produced by neutrophils in the context of their normal stimulation by phagocytosis or other types of activating agents. The most elusive of these was ozone. In an exciting collaboration that was ongoing at the time of his death, Bernie was working with Richard Lerner, Paul Wentworth, and other colleagues at The Scripps Research Institute on studying the unexpected ability of antibodies to catalyze the formation of ozone from hydrogen peroxide and singlet oxygen, a reaction of great potential significance in the context of the stimulated neutrophils, in which superoxide, hydrogen peroxide, singlet oxygen, and $\mathrm{HOCl}$ are generated usually in the presence of antibodies - bound either to opsonized microbes or to the neutrophil cell membrane (17). The range of reactive oxygen intermediates produced by phagocytic cells has opened broad new perspectives for understanding both the beneficial mechanisms of microbial killing and the harmful effects of acute and chronic inflammation.

What Bernie couldn't predict was the way in which our discovery of superoxide production by neutrophils would affect the courses of our lives. Bernie eventually changed his medical specialty from gastroenterology to hematology, passed his specialty boards, and became a worldrenowned leader in academic hematology. His numerous research accomplishments were recognized by the National Academy of Sciences when he was elected as a member in 2000. Bernie and I developed a lifelong close friendship in which he was not only my mentor, but my scientific father. I was his scientific son and, perhaps appropriately, became a pediatric hematologist/ oncologist. Bernie moved back to California, his beloved home state, in 1985, when he became the head of Biochemistry at Scripps. In 1986 he recruited me to Scripps to join his department and thereby opened one of the most productive phases of both of our careers when we collaborated extensively for the next 4 years. We dreamed of developing novel anti-inflammatory drugs based on our growing understanding of the oxidase. I made the jump to biotechnology at Genentech and then to DNAX to pursue that dream, while Bernie, a true academic at heart, remained at Scripps but cheered me on at each subsequent step of my career. I was at his bedside the night he died. As he was peacefully leaving this world, I spoke to him about our first experiments together and asked if he remembered what a remarkable experience it was to see for the first time 
that neutrophils made superoxide. With the little strength he had left, he smiled.

Address correspondence to: John T. Curnutte, DNAX Research Inc., 901 California Avenue, Palo Alto, California 94304, USA. Phone: (650) 496-1206; Fax: (650) 4961107; E-mail: john.curnutte@dnax.org.

1. Babior, B.M., Kipnes, R.S., and Curnutte, J.T. 1973. Biological defense mechanisms. The production by leukocytes of superoxide, a potential bactericidal agent. J. Clin. Invest. 52:741-744.

2. Fridovich, I., and Handler, P. 1961. Detection of free radicals generated during enzymic oxidations by the initiation of sulfite oxidation. J. Biol. Chem. 236:1836-1840.

3. Misra, H.P., and Fridovich, I. 1972. The generation of superoxide radical during the autoxidation of hemoglobin. J. Biol. Chem. 247:6960-6962.

4. McCord, J.M., and Fridovich, I. 1969. Superoxide dismutase. An enzymic function for erythrocuprein (hemocupreine). J. Biol. Chem. 244:6049-6055.

5. McCord, J.M., Keele, B.B., Jr., and Fridovich, I. 1971 An enzyme-based theory of obligate anaerobiosis: the physiological function of superoxide dismutase. Proc. Natl. Acad. Sci. U. S. A. 68:1024-1027.

6. Sbarra, A.J., and Karnovsky, M.L. 1959. The biochemical basis of phagocytosis. I. Metabolic changes during the ingestion of particles by polymorphonuclear leukocytes. J. Biol. Chem. 234:1355-1362.

7. Iyer, G.Y.N., Islam, M.F., and Quastel, J.H. 1961. Biochemical aspects of phagocytosis. Nature. 192:535-541.

8. Klebanoff, S.J. 1967. Iodination of bacteria. A bactericidal mechanism. J. Exp. Med. 126:1063-1078.

9. Lehrer, R.I., and Cline, M.J. 1969. Leukocyte myeloperoxidase deficiency and disseminated candidiasis: the role of myeloperoxidase in resistance to Candida infection. J. Clin. Invest. 48:1478-1488.

10. Curnutte, J.T., and Babior, B.M. 1974. Biological defense mechanisms. The effect of bacteria and serum on superoxide production by granulocytes. J. Clin. Invest. 53:1662-1672.

11. Holmes, B., Page, A.R., and Good, R.A. 1967. Studies on the metabolic activity of leukocytes from patients with a genetic abnormality of phagocyte function. J. Clin. Invest. 46:1422-1432.

12. Pincus, S.H., and Klebanoff, S.J. 1971. Quantitative leukocyte iodination. N. Engl. J. Med. 284:744-750.

13. Curnutte, J.T., Whitten, D.M., and Babior, B.M. 1974. Defective superoxide production by granulocytes from patients with chronic granulomatous disease. N. Engl. J. Med. 290:593-597.

14. Babior, B.M., Curnutte, J.T., and McMurrich, B.J. 1976. The particulate superoxide-forming system from human neutrophils. Properties of the system and further evidence supporting its participation in the respiratory burst. J. Clin. Invest. 58:989-996.

15. Curnutte, J.T., Kipnes, R.S., and Babior, B.M. 1975. Defect in pyridine nucleotide dependent superoxide production by a particulate fraction from the granulocytes of patients with chronic granulomatous disease. N. Engl. J. Med. 293:628-632.

16. Babior, B.M. 2004. NADPH oxidase. Curr. Opin. Immunol. 16:42-47.

17. Babior, B.M., Takeuchi, C., Ruedi, J., Gutierrez, A., and Wentworth, P. 2003. Investigating antibodycatalyzed ozone generation by human neutrophils. Proc. Natl. Acad. Sci. U. S. A. 100:3031-3034. 